\title{
Comicidade crítica e riso autodepreciativo: um estudo com mulheres palhaças
}

\author{
Ana Carolina Muller Fuchs ${ }^{1}$ (iD) 0000-0001-8630-8812 \\ Gilberto lcle ${ }^{1,2}$ (iD) 0000-0001-7961-4782 \\ 'Universidade Federal do Rio Grande do Sul, Programa de Pós-Graduação em \\ Educação, Porto Alegre, RS, Brasil. 90046-900-ppgedu@ufrgs.br \\ 2Universidade de Brasília, Programa de Pós-Graduação em Artes Cênicas, Brasília, DF, \\ Brasil.70910-900 - secretariapgcen@unb.br
}

\section{$-$}

Resumo: O presente artigo propõe uma reflexão sobre as questões de gênero que envolvem as práticas da palhaçaria feminina, a partir do convívio e de entrevistas com um grupo de mulheres palhaças no Brasil. Trabalha-se a ideia de que os discursos sociais forjam os corpos e os padrões de gênero e, portanto, perpassam os processos criativos na palhaçaria. Com base no conceito de práticas parodísticas desenvolvido por Judith Butler, este trabalho busca pensar nos processos da palhaçaria feminina no seu caráter de paródia de si e em suas reverberações na criação de uma comicidade crítica e não autodepreciativa. Propõe-se o conceito de paródia a partir dos trabalhos de Judith Butler, Linda Hutcheon e Giorgio Agamben como forma de delinear a noção de paródia na qualidade de distanciamento crítico e na possibilidade de afetar os modos de subjetivação das artistas.

Palavras-chave: gênero; palhaçaria feminina; paródia; subjetividade.

\section{Critic Comicality and Self-derogatory Laugh: A Study with Female Clowns}

Abstract: This paper proposes a reflection on gender issues involving female clowning practices, based on the coexistence and interviews with a group of female clowns in Brazil. It develops the idea that social discourses forge bodies and gender standards, therefore crossing the creative processes in clowning. Founded on the concept of parodistic practices developed by Judith Butler, this work aims to think on the processes of female clowning in its character of parody of oneself, as well as on its reverberations in the creation of a critic and non-self-derogatory comicality. The concept of parody is proposed based on the works of Judith Butler, Linda Hutcheon and Giorgio Agamben as a way of outlining the notion of parody in the quality of critical detachment, and in the possibility of affecting the female artists' modes of subjectivation.

Keywords: Gender; Female clowning; Parody; Subjectivity.

\section{Introdução}

A ałuação da mulher como palhaça nem sempre foi algo possível. A tradição de repassar e perpetuar os ensinamentos referentes à palhaçaria' foi, por muito tempo, de domínio masculino. Amanda Leite (2015) apresenta um panorama de mulheres palhaças que atuaram em circos norte-americanos e europeus como algo pontual e incomum. A autora cita Amélia Butler, que em 1858 acompanhou o Nixon's Great American Circus nos Estados Unidos e que tinha uma caracterização "evidentemente feminina". Da mesma forma, Evetta Mathews era anunciada como

\footnotetext{
' Segundo a pesquisadora Sarah Santos (2014), a palavra palhaçaria é uma derivação da palavra francesa clownerie e se refere tanto às práticas de composição da figura do palhaço e da palhaça quanto aos demais elementos que compõem o processo criativo dessa arte cômica, como suas ações, repertórios e técnicas. Para o pesquisador Demian Reis (2013, p. 20), a palhaçaria se refere às "[...] ações cômicas do palhaço e à recepção."
} 
atração por ser a "única mulher palhaça" (ADAMS; KEENE, 2012 apud LEITE, 2015, p. 15). No Brasil, a tradição circense também designava a função do palhaço somente aos homens: "Diziam os tradicionais que mulher não podia ser palhaço. E falavam assim mesmo, no masculino, tão forte era a associação do personagem com o gênero" (Alice CASTRO, 2005, p. 220). Conforme Ermínia Silva e Luís Alberto de Abreu (2009) e Santos (2014), no circo, as mulheres participavam do espetáculo, porém não podiam ser palhaças, por trabalhar com uma corporalidade grotesca, maliciosa e que tem contato direto com o público. Elas também não podiam 'fazer a praça', (fazer os contatos e as tratativas comerciais na cidade), porque os artistas, principalmente as mulheres, sofriam muitos preconceitos e "[...] procuravam proteger-se (e também às suas mulheres e filhas) dos olhares da cidade" (SANTOS, 2014, p. 21). As primeiras mulheres que ocuparam o papel de palhaço, o fizeram vestidas de homem ou acompanhadas por seus maridos ou pais. Em relação ao trabalho cômico desenvolvido por mulheres no espaço circense, ainda é possível pontuar a participação feminina nas diferentes formas do circo, como circo tradicional, circo-família e no circo novo ou contemporâneo.

Com a constituição das primeiras escolas de circo $^{2}$, diferentes profissionais passaram a ter acesso à arte circense, novas metodologias foram criadas e, consequentemente, as mulheres tiveram maior acesso à palhaçaria. Contudo, os discursos que impregnavam as práticas circenses se estenderam também para esses espaços. Nas escolas de circo brasileiras as mulheres tiveram a oportunidade de treinar e ensaiar números de palhaço, entretanto, não podiam integrar os espetáculos. Conforme relato de Verônica Tamaoki, aluna de uma das primeiras escolas de circo, em entrevista concedida a Santos (2014, p. 77), a arte da palhaçaria era ensinada para homens e mulheres, mas eles não as deixavam se apresentar no picadeiro com "número de palhaço". A arte da palhaçaria, portanto, seguiu atravessada por uma série de discursos que subordinavam e sujeitavam a artista-mulher. Mesmo propagando algumas práticas que ainda limitavam a participação feminina na palhaçaria, as escolas de circo foram fundamentais para que as mulheres se apropriassem dessa arte, rompendo com as tradições restritivas impostas. Beryl Hugill (1980), ao traçar um percurso da história da palhaçaria nos Estados Unidos, aponta para a participação das mulheres, principalmente a partir das escolas de circo, como um sinal de ruptura com a tradição masculina. Em relação ao contexto brasileiro, Leite (2015, p. 40) assinala "[...] a constituição de novos sujeitos históricos que passaram a participar da construção da linguagem circense a partir da década de 1980." Sujeitos estes originários de diferentes segmentos sociais e variadas formações profissionais e que não necessariamente se dedicaram ao circo posteriormente, mas estenderam esses saberes a outras atividades artísticas. Segundo a autora, os processos de ensino-aprendizagem desses novos artistas, que passaram a experimentar a arte circense a partir das escolas de circo, exigiram a estruturação de novas metodologias, diferentes daquelas vividas pelo circo-família. É possível, ainda, mapear diferenças nas participações cômicas femininas tanto no que se refere à participação artística quanto às relações econômicas nas diversas expressões do circo como: circo tradicional, circo-família, circo-teatro e circo novo. No entanto, é necessário pontuar que essas modalidades circenses estão inseridas em contextos sociais e épocas diferentes o que complexifica ainda mais as análises a respeito da participação feminina no espaço circense.

Pensar as produções circenses, através das ações de seus vários sujeitos, pode revelar as distintas formas de fazer circo e as mais diferentes maneiras de ser artista circense, além de dar pistas sobre os diálogos que estabeleciam com os movimentos culturais de sua época. (SILVA, 2003, p. 38).

Se, por um lado, a história da palhaçaria é contada pelo viés do circo, justamente porque é nesse espaço que a figura do palhaço se consolida, por outro, também, é possível contar essa trajetória tendo como base as aproximações com o teatro. Segundo Mário Bolognesi (2003, p. 194), o palhaço é um ponto de ligação entre o circo e o teatro: "A aproximação do espetáculo circense com os teatros londrinos possibilitou, principalmente, a depuração de um tipo cômico e um modo cênico muito particular, que tem sua filiação com outros momentos da história dos espetáculos." Cabe, então, estender o olhar para as interlocuções entre circo e teatro, buscando compreender como esse diálogo foi agente de transformação tanto na cena, quanto nas metodologias em palhaçaria. A relação do teatro com a palhaçaria, além de ampliar o acesso das mulheres, instigou a criação de metodologias baseadas na subjetividade das artistas ${ }^{3}$. Mariana Junqueira

\footnotetext{
${ }^{2}$ A primeira escola de circo data de 1920 na antiga União Soviética. Nos Estados Unidos, foi fundada em 1968 Ringling Bros. and Barnum \& Bailey Clown College. Na Europa, tem-se o registro da escola fundada por Annie Fratellini, a L'école Nationale du Cirque. No Brasil, a primeira escola de circo, a Academia Piolim de Artes Circenses, foi fundada em 1978, em São Paulo. Na década seguinte foi criada pelo Governo Federal a Escola Nacional de Circo no Rio de Janeiro e, em 1985, foi criada a Escola Picolino de Artes do Circo na Bahia, fundada por artistas que não tinham descendência circense.

${ }^{3}$ Nós não encontramos, até o momento, pesquisas que possam dar suporte e informações sobre as diferenças de tratamento às mulheres palhaças no circo e no teatro no Brasil. Não há dados disponíveis sobre diferenças de contrato, diferenças salariais, preconceitos no ambiente de trabalho e outros dados que poderiam oferecer um panorama da situação profissional das mulheres palhaças no Brasil.
} 
(2012) ressalta uma diferença entre as metodologias adotadas pelo circo e o teatro na composição da palhaçaria. Segundo a autora:

Enquanto o ator busca por seu ridículo e por sua lógica particulares e cria seu próprio repertório a partir de jogos de improviso, os circenses partem da tradição, de esquetes e entradas clássicas, de gags físicas para construírem seu trabalho, muitas vezes herdando do pai ou do palhaço que o antecedeu naquela lona até mesmo nome e figurino. (JUNQUEIRA, 2012, p. 23).

Uma das principais referências das metodologias de exploração do universo pessoal de artistas para a criação da máscara é Jacques Lecoq (2010) que, em 1960, desenvolveu um modo de pesquisa para a composição do clown ${ }^{4}$ a partir das particularidades risíveis de cada ator, 0 clown próprio de cada um. O autor explica: "Com o clown, eu lhes peço que sejam eles mesmos, o mais profundamente possível, e que observem o efeito que produzem no mundo, a saber, no público." (LECOQ, 2010, p. 219).

Castro (2005) também aponta para diretores-pedagogos europeus e suas influências na formação de palhaços brasileiros que, por sua vez, estenderam seu aprendizado a outros artistas no Brasil. Bolognesi (2006) também trata da relação entre os profissionais europeus e brasileiros que disseminaram as técnicas de clown no Brasil, especialmente a partir de 1980. Segundo o autor: "[...] atores e diretores teatrais tiveram a oportunidade de experimentar técnicas clownescas filtradas por diferentes diretores franceses, especialmente Decroux e Lecoq." (BOLOGNESI, 2006, p. 14).

O entrelaçamento entre circo e teatro constituiu metodologias próprias que influenciam até hoje os processos formativos em palhaçaria no Brasil. Contudo, mesmo com a possibilidade de as mulheres atuarem como palhaças nesse contexto, as artistas enfrentaram uma série de desafios e dificuldades, principalmente em relação às questões de gênero que constituem a máscara como domínio masculino. Grande parte do repertório e das referências em palhaçaria é de palhaçoshomens, as metodologias pouco exploravam as questões de gênero e os espaços de ałuação para as mulheres-palhaças também eram restritos. Diante disso, as artistas-palhaças passaram a se organizar. A palhaçaria feminina como movimento ${ }^{5}$, com uma pauta de ações que questiona o domínio masculino nessa arte, que busca visibilidade e espaços de trabalho para a artistapalhaça e que explora metodologias de criação diferenciadas, se difunde e se expande, principalmente a partir da década de 1990, por intermédio da formação de grupos de mulherespalhaças, da criação de festivais específicos e, sobretudo, a partir de processos formativos direcionados especialmente às mulheres, como apontam as pesquisas de diversas mulherespalhaças, por exemplo, Santos (2014), Junqueira (2012) e Leite (2015).

A palhaçaria feminina emerge pautada por práticas que reivindicam um olhar sobre as relações de gênero e suas implicações nos modos de composição da máscara-palhaça. O percurso das mulheres na palhaçaria exigiu das artistas a busca de formas próprias de compor a figura da palhaça, de aprender, de construir seus processos e seu repertório, numa relação íntima entre os princípios básicos que conduzem a formação da máscara-palhaça e o universo que as cerca. Além disso, constituiu uma rede de saberes que se estende para além dos limites da ação cênica das artistas, compondo, assim, o que podemos chamar de pedagogias da palhaçaria feminina. Pedagogias estas que não tratam somente de uma metodologia de aprendizagem da máscara-palhaça, mas que perpassam toda a prática artística e reverberam nos modos pelos quais as artistas compreendem e transformam a própria existência.

Muitos processos criativos da palhaçaria feminina envolvem a relação entre o universo pessoal das artistas com a formação da figura palhaça. Essa abordagem não é exclusiva da palhaçaria feminina e foi constituída, principalmente, na intersecção entre as metodologias de circo e de teatro. Entretanto, possibilitou às artistas-palhaças desenvolverem diferentes práticas que abarcam suas necessidades, que as representam, que dialogam com seus anseios, que traduzem suas perspectivas de mundo e que são transformadoras de suas próprias vidas. Nesse sentido, o processo pedagógico de constituição de si que as metodologias de composição da máscara palhaça propiciaram às mulheres tornou-se um pilar da palhaçaria feminina.

\footnotetext{
${ }^{4}$ Segundo Luís Otávio Burnier (2009, p. 205), "[...] palhaço e clown são termos distintos para designar a mesma coisa." Diferem-se etimologicamente quanto a suas linhas de trabalho e práticas. O clown ou palhaço é um tipo cômico que tem como função questionar normas sociais por intermédio do riso. Neste artigo optou-se por manter a terminologia palhaço e palhaça, tendo em vista a maneira como cada artista pesquisada se refere a si e a seu trabalho. Da mesma forma, em algumas citações específicas, foram mantidas as terminologias utilizadas pelas autoras e pelos autores. ${ }^{5}$ Neste estudo a ideia de movimento da palhaçaria feminina refere-se às diferentes ações - como oficinas, festivais e pesquisas - constituídas por artistas-palhaças para discutir as relações de gênero e a máscara. Atualmente, no Brasil, conforme levantamento apresentado no material gráfico do festival Esse Monte de Mulher Palhaça (2017), existem cerca de 13 festivais destinados à palhaçaria produzida por mulheres, nas diferentes regiões brasileiras. Em São Paulo foi fundada a primeira Escola de Palhaças do Brasil, criada e coordenada por Andréa Macera, palhaça Mafalda Mafalda do Teatro da Mafalda. No estado de Santa Catarina, a artista Michelle Silveira, palhaça Barrica, é a idealizadora e editora da Revista de Palhaçaria Feminina, única no país sobre o tema, a revista está em sua quarta edição. No mesmo estado as artistas palhaças estão organizadas na Rede Catarina de Palhaças, inspiradas pela criação da Rede Nacional de Palhaçaria Feminina. Esses são alguns exemplos das muitas ações de mulheres palhaças no território nacional.
} 
Assim, é no contexto do movimento de palhaças brasileiras que produzimos a pesquisa que deu origem a este artigo. Entrevistamos 15 mulheres palhaças de diferentes estados brasileiros e convivemos com elas durante três eventos de palhaças ${ }^{6}$.

Para entendermos o modo como essas mulheres produzem rupturas em relação ao que compreendemos como gênero e como produzem uma pedagogia (aqui entendida como práticas de subjetivação) que possibilita fazer das práticas da palhaçaria modos de resistência, analisamos alguns dados (retirados das entrevistas e de nossas anotações in loco) e operamos com base na noção de práticas parodísticas desenvolvida por Judith Butler (2016). Em linhas gerais, o conceito trata da noção de gênero como paródia, uma imitação de modelos socialmente instituídos. Dessa forma, entendemos que as práticas de elaboração da figura da palhaça que estão baseadas no universo pessoal feminino da artista podem ser vistas como processo pedagógico que se dá a partir de processos criativos de paródias de si.

O conceito de pedagogia tem sido explorado em diferentes configurações, e é utilizado inclusive no plural, multiplicando os olhares sobre o termo: pedagogias da infância, pedagogias de gênero, pedagogias teatrais e tantas outras. Viviane Camozzato (2014) observa que a proliferação do conceito de pedagogia acontece em virtude da multiplicidade de abordagens possíveis conforme os contextos, as ênfases e as práticas que a envolve. As "pedagogias do presente", como a autora denomina, têm por finalidade a produção de sujeitos e discursos já que: "De fato, o uso desse conceito vem sendo empregado para mostrar a operacionalidade de discursos específicos em artefatos que se dispõem a educar e a produzir determinados tipos de sujeitos." (CAMOZZATO, 2014, p. 574).

Em função desse olhar voltado a si mesma e das especificidades das práticas femininas de fazer rir, nós nos perguntamos: como é possível, parodiar a si e rir das questões que envolvem gênero de forma transformadora, sem que isso seja depreciativo? Assim, este artigo trata da paródia de si presente nas práticas da palhaçaria feminina em seu caráter pedagógico, em sua possibilidade de gerar posicionamento crítico e reverberar nos modos de subjetivação das artistas, nas formas de compreensão e de constituição de si.

\section{Palhaçaria como questão de gênero, sim}

As questões de gênero ainda constituem um campo de tensionamento e questionamento na palhaçaria, que vem sendo cada vez mais explorado pelas artistas-palhaças-pesquisadoras. Longe de querer abarcar todos os aspectos dessa discussão, este trabalho propõe um olhar para as práticas desenvolvidas pelas artistas e sobre as implicações entre as questões de gênero que perpassam seus corpos e os processos criativos das palhaças.

A composição da figura palhaça, embora calcada em uma máscara universal, carrega elementos subjetivos da artista, portanto, depende do encontro desta com os discursos que a atravessam, que compõem seus corpos. A palhaça evidencia e amplia as suas características físicas e emocionais, principalmente, em busca do que lhe é estranho, feio ou desajustado. O que compõe o corpo da artista é colocado à mostra e a serviço das situações cômicas. Nessa construção, ela é confrontada com seus diferentes registros físicos, emocionais e mentais, por meio de situações que buscam romper com suas defesas cotidianas para reconhecer e apanhar o que permeia seu universo.

Para Butler (2002a, p. 163) os discursos sociais "[...] habitam corpos. Eles se acomodam em corpos; os corpos na verdade carregam discursos como parte de seu próprio sangue." Nesse sentido, as questões de gênero emergem e passam a fazer parte da composição da máscarapalhaça. Adelvane Néia (2015), uma das primeiras artistas-palhaças a desenvolver um trabalho formativo voltado para mulheres no Brasil, pontua que as construções sociais femininas formam registros corporais e é neles que a construção da figura da palhaça se apoia.

Castro (2005, p. 222) enfatiza que a criação em palhaçaria é algo "pessoal, único e intransferível" e, portanto, as questões de gênero estão, sim, presentes na composição da figura que, mesmo sendo masculina na sua origem, contém a perspectiva de uma mulher na sua composição. Ainda que uma mulher personifique uma figura masculina, será sempre sobre o viés de seu corpo carregado de significados que se exteriorizam em seu comportamento cênico. De acordo com a autora:

Falar da sexualidade do palhaço é assunto complexo. Alguns palhaços são claramente masculinos; outros, no entanto, são tão líricos e inocentes que deixam longe essas questões de gênero e sexo, que parecem não ter qualquer importância na construção da persona-palhaço.

\footnotetext{
${ }^{6}$ No período compreendido entre março de 2017 e dezembro de 2018 foram realizadas sete entrevistas individuais e quatro rodas de conversa envolvendo ao todo 15 artistas-palhaças. Também foram observados e descritos cenas e espetáculos apresentados nos seguintes festivais: II Mostra Tua Graça Palhaça (Porto Alegre/RS, 2017), $7^{\circ}$ festival Esse Monte de Mulher Palhaça (Rio de Janeiro/RJ, 2018) e $1^{\circ}$ Sol Rindo (Camboriú/SC, 2018). Também foram acompanhados debates e mostras de documentários que constituíam a programação desses eventos. Ainda como material de composição desta pesquisa, foram feitas observações participantes em duas oficinas de palhaçaria com as artistas-palhaças Andrea Macera e Karla Concá.
} 
É claro que isso é um engodo. O fato do artista criador ser um homem ou uma mulher muda o personagem - mesmo que isso não seja percebido num primeiro momento, nem no segundo. O Souza da Ângela de Castro só poderia ter sido criado por ela. E ela é uma mulher. Assim como o Dr. Giramundo - o pernóstico, afetado e falastrão palhaço da Yeda Dantas - é fruto da visão e das experiências dela, que é uma mulher. (CASTRO, 2005, p. 222).

Cabe mencionar, neste momento, um exemplo que revela as implicações das questões de gênero nas práticas da palhaçaria feminina. A artista Michelle Silveira, palhaça Barrica, durante a entrevista para esta pesquisa, relatou que, em seu processo de composição da figura, passou por diferentes etapas de exploração de elementos relacionados a gênero. Primeiro, sua figura remetia ao universo considerado masculino, que incluía um figurino composto por calça e colete, assim como apresentava ações mais grotescas, até começar a explorar as características femininas na sua criação cômica. Ela conta:

A minha primeira roupa era uma roupa meio, não é bem feminina nem masculina, era uma roupa. Uma calça justa azul ligadinha e um colete xadrez e um laço amarelo no peito. Mas, eu era muito infantilizada. [...] Daí entrou a masculinização da figura. Ela me sugeriu de colocar um paletó e uma peruca curta. [...] Quando entrava o feminino, pela primeira vez eu entrava com a mesma calça justa e um maiô tomara que caia listrado colorido e uma flor no cabelo. E aí, as pessoas adoravam. [...] Então, eu lembro que desfilei assim: tinha uma passarela naquela feira e eu tirei o casaco e desfilei e no tirar o casaco eu ficava com a barriga toda de fora e a mulherada gritava assim, muito louca! Aquilo para mim foi muito forte, me marcou muito, porque eu sabia que elas se viam em mim, elas se viam em mim, sabe. E aí eu pensei - olha que legal, eu mostro aquilo que elas gostariam de mostrar e não têm coragem. Talvez eu encoraje elas a mostrar, porque eu também comecei a mostrar, a não me importar tanto com meu corpo, a ver meu corpo de uma outra forma. E também fiquei pensando que elas olham para mim e se aliviam pensando que - a barriga dela é maior que a minha! Graças a Deus, e eu nem sou tão gorda assim. (Michelle Silveira, palhaça Barrica).

O trabalho desenvolvido por Michelle, que brinca com suas formas físicas, pode nos ajudar a pensar em como a noção de gênero está inscrita nos mínimos detalhes que interpelam os sujeitos ao longo da vida e se fazem como ato, como forma. Da mesma forma, nos permite pensar na relação íntima entre as construções pessoais e sociais, visto que a individualidade é forjada por uma série de referências coletivas. No relato acima é possível mapear diferentes referenciais em relação aos marcadores femininos e masculinos, como a roupa, os adereços e a relação do próprio corpo com os modelos de gênero. As categorias de masculinidade e feminilidade pressupõem uma rede de códigos comuns que as caracteriza nas suas diferenças.

Guacira Louro (2008) explica como as ideias de gênero e de sexualidade são uma construção social e se dão nas práticas e aprendizagens cotidianas, de formas explícitas ou dissimuladas, nas mais diversas instâncias sociais e culturais. Trata-se de um

processo minucioso, sutil, sempre inacabado. Família, escola, igreja, instituições legais e médicas mantêm-se, por certo, como instâncias importantes nesse processo constitutivo. Por muito tempo, suas orientações e ensinamentos pareceram absolutos, quase soberanos. Mas como esquecer, especialmente na contemporaneidade, a sedução e o impacto da mídia, das novelas e da publicidade, das revistas e da internet, dos sites de relacionamento e dos blogs? Como esquecer o cinema e a televisão, os shopping centers ou a música popular? Como esquecer as pesquisas de opinião e as de consumo? E, ainda, como escapar das câmeras e monitores de vídeo e das inúmeras máquinas que nos vigiam e nos 'atendem' nos bancos, nos supermercados e nos postos de gasolina? Vivemos mergulhados em seus conselhos e ordens, somos controlados por seus mecanismos, sofremos suas censuras. (LOURO, 2008, p. 18, grifo da autora).

Louro, então, demonstra como a noção de gênero é constituída em diferentes e mínimas práticas, nas diferentes esferas cotidianas. A noção de gênero é, portanto, delimitada por inúmeros marcadores sociais que forjam os corpos e permitem seu reconhecimento. Sob essa perspectiva é possível observar, no relato de Michelle, como os diferentes dispositivos de gênero geram o reconhecimento de um grupo de pessoas que também compartilham dos mesmos quadros normativos.

As interlocuções entre o que é pessoal e social tornam-se um ponto-chave na composição da figura da palhaça. Ao explorar o que perpassa seus corpos e sua relação com o mundo, a artista reconhece elementos que permeiam a rede discursiva que a constitui e que fazem parte de uma coletividade. Quando esses elementos são retrabalhados e apresentados a partir da máscarapalhaça, a artista cria condições de compartilhar esse reconhecimento de forma crítica, possibilitando um dilatamento dos olhares em relação às normas que compõem as noções de gênero, conferindo outras possibilidades para essas configurações. Michelle revela que, ao expor seu corpo fora dos padrões, as mulheres da plateia se identificaram com a sua palhaça e ficaram eufóricas ao se reconhecerem naquela figura. Percebe-se um deslocamento entre a perspectiva individual de construção do trabalho e a transposição para seu nível social, como duas dimensões interligadas, tendo em vista que os discursos sociais forjam os corpos e esses, por sua vez, em sua 
individualidade, apresentam o caráter coletivo. Dessa forma, ainda é possível olhar para o relato de Michelle pelo viés do deslocamento dos efeitos de riso, já que, segundo a artista, ela mesma mudou sua relação com o próprio corpo, colocando em xeque padrões normativos corporais e de gênero e teve a empatia do público feminino, pois as mulheres se identificam com sua figura. É possível, então, pensar na transposição e no efeito de riso que poderia ser depreciativo do corpo da artista para um riso empático de reconhecimento e ruptura crítica dos padrões normativos.

Butler (2016) defende a noção de gênero como uma criação cultural e social. Para a autora, gênero não é e não pode ser entendido como algo natural, pré-determinado, dado por um corpo biológico e anatomicamente constituído. Entende-se, portanto, que a construção de gênero é o resultado de práticas sociais que significam os corpos e que criam a falsa ideia de algo natural. Ainda segundo Butler, gênero é um ato performativo, pois se inscreve na superfície dos corpos a partir de atos, gestos e atuações repetitivas, produzidas e sustentadas por "signos corpóreos e outros meios discursivos" (BUTLER, 2016, p. 235). Assim, a noção de gênero como ato performativo parte do pressuposto de que a realidade de gênero só existe quando representada, dramatizada, diante do outro por intermédio de performances sociais.

Dessa forma, tendo como princípio que a composição da figura da palhaça se apoia na exploração do universo pessoal de cada artista e que essa individualidade também é uma construção social, a manifestação das questões de gênero que forjam os corpos e as vidas das artistas é inerente ao processo de composição da máscara palhaça. Contudo, não se trata apenas de trazer para a palhaça e para a cena temas relacionados ao feminino, trata-se também da constituição de processos artísticos em que as questões de gênero instigam outras formas de habitar a máscara, de criar repertório, de provocar o riso, de criar procedimentos e métodos que reverberam na estética da cena. Pensar sobre as práticas pedagógicas da palhaçaria feminina e das relações de gênero que ela implica pode permitir estender o olhar para as possibilidades de transformação da máscara e do repertório da palhaçaria.

Para Maria Brígida de Miranda (2008), o teatro feminista, aquele engajado nas causas e discursos feministas, precisa ser mais que uma abordagem de temas femininos, precisa ser, sobretudo "[...] uma transformação na prática teatral, tanto no conteúdo e estética de peças teatrais quanto nas estratégias de criação e trabalho." (MIRANDA, 2008, p. 137). Essa perspectiva vai ao encontro das propostas pedagógicas da palhaçaria feminina, que refletem os discursos de gênero não somente nos temas, mas também em suas diferentes práticas. Talvez seja possível pensar que a palhaçaria feminina se constitua justamente por meio de suas pedagogias, de seus modos de experimentação, pela busca de novas práticas criativas e de práticas que reverberam na constituição das sujeitas.

\section{A palhaçaria feminina como paródia de si}

É a liberdade de poder errar e não ser criticada. De poder errar e rir disso e fazer o outro rir ainda. (Karla Concá).

A frase acima é de Karla Concá, referindo-se ao seu processo de formação como palhaça durante entrevista realizada para este trabalho. Karla, artista-palhaça-formadora, integrante de um dos primeiros grupos de mulheres palhaças do Brasil, as Marias da Graça, fala do sentimento de liberdade que experimentou por intermédio das práticas da palhaçaria. Liberdade em relação ao erro, à crítica e aos julgamentos sociais. A fala da artista nos possibilita pensar em como os comportamentos são regidos por regras e normas que estabelecem os padrões de certo e de errado e que afetam os modos de ser dos indivíduos. Com a palhaçaria feminina, a artista encontrou espaço para o erro, para a transgressão, para experimentar o que não é permitido ou visto como adequado socialmente.

A noção de desajuste, ridículo, torpe, também é uma construção social, fabricada dentro dos próprios quadros normativos que regulam as noções de adequado e inadequado. $O$ desajuste contém a norma e vice-versa, ou ainda o desajuste está na própria norma. A estrutura da figura da palhaça que se dá com a exploração do que cada artista reconhece como desajuste e torpe evidencia que há uma composição de si que se constituiu por intermédio da norma. Nesse sentido, Butler (2015) afirma que o corpo adquire significado dentro de uma rede discursiva que lhe confere reconhecimento.

Com base na teoria de Michel Foucault, Butler ratifica a ideia de que o reconhecimento de si se dá pelos regimes de verdade, que se constituem fora do sujeito, pelas regras e normas que lhe conferem legitimidade, mas que, necessariamente, não o determinam. Ao mencionar Foucault, a autora afirma que

sempre haverá uma relação com esse regime, um modo de engendramento de si que acontece no contexto das normas em questão e, especificamente, elabora uma resposta para a pergunta sobre quem será 'eu' em relação a essas normas. Nesse cenário, nossas decisões não são determinadas pelas normas, embora as normas apresentem o quadro e o ponto de referência 
para quaisquer decisões que venhamos a tomar. Isso não significa que dado regime de verdade estabeleça um quadro invariável para o reconhecimento; significa apenas que é em relação a esse quadro que o reconhecimento acontece, ou que as normas que governam 0 reconhecimento podem ser contestadas e transformadas. (BUTLER, 2015, p. 35.

A reflexão de Butler apresenta a relação entre as práticas discursivas socialmente constituídas e os modos de subjetivação, à medida que o sujeito se elabora frente à rede discursiva que o interpela, todavia, a elaboração de si se dá a partir de movimentos de aceitação, resistência e subversão às normas. O trabalho da palhaça pode ser visto nessa perspectiva de contestação dos regimes de verdade justamente porque desloca do plano pessoal para o social as noções de fracasso e desajuste.

Para explorar um pouco mais essa relação entre pessoal e social na constituição da noção de fracasso e ridículo que perpassa a composição da máscara-palhaça, apresentamos outro relato da artista Michelle Silveira, a palhaça Barrica. Ao falar de sua relação com os padrões corporais e a composição de sua figura, ela conta como passou a reconhecer seu corpo e suas possibilidades cômicas a partir da crítica e do questionamento aos padrões normativos de beleza e feminilidade. Em seu relato, Michelle apresenta o processo de construção de seu novo número cômico, envolvendo a figura da lemanjá. A partir das relações entre seu corpo e a construção de seu figurino, a artista explicita como o trabalho com a palhaçaria feminina e a composição de sua palhaça alterou a sua relação consigo mesma.

A ideia inicial para o trabalho era fazer um maiô que se assemelhasse à cor de sua pele com um bustiê sobreposto e uma saia de sereia. Entretanto, ao experimentar a combinação bustiê/ saia, sem o maiô, e que isso evidenciava suas formas corporais, Michelle gostou do resultado, não sentindo necessidade de cobrir aquelas partes que outrora lhe causavam desconforto ou vergonha. Nas palavras dela:

Então, para mim é muito forte porque tem essa figura feminina, vem a questão da sereia, vem a questão do padrão, porque a gente nunca vê sereia gorda, a gente só vê sereia magra. Vem essa quebra de padrão. Por que elas não podem ser diferentes? [...] Para mim foi ótimo! Porque eu ia fazer a saia e ia fazer um maiô da cor da pele e a coisa aqui, o bustiê. Quando eu fui na costureira e ela tinha um bustiê e a saia, ela disse: 'não sei como vou fazer o maiô'. E eu disse: nem faça porque ficou maravilhoso. Eu adorei. É isso aí, as gorduras, os pneus, é isso que vai, entendeu. Porque isso para mim tá tranquilo já, tem que lidar com isso e usar isso a meu favor para desmistificar isso de que a beleza não tá só no teu tamanho, no teu peso. A beleza vai muito além, a feminilidade também.

É possível depreender desse relato a relação da artista com o próprio corpo que, por não se enquadrar nos padrões da beleza pautados em corpos magros, encontra na figura da palhaça um espaço de existência, resistência e reconhecimento. Ao brincar com a própria imagem, expor seu corpo fora dos padrões de peso, também brinca, debocha e possibilita uma crítica ao que é dado como ridículo. Por que corpos gordos não podem ser considerados interessantes e bonitos? A composição da figura da palhaça Barrica como sereia e a criação de seu repertório, feitas por Michelle, possibilita uma crítica aos discursos que interpelam os sujeitos e padronizam corpos e comportamentos para que os indivíduos se encaixem em modelos reconhecidos e aceitos socialmente. Dessa maneira, a noção de desajuste aponta para as construções sociais e não para a individualidade da artista, configurando novamente um deslocamento dos efeitos de riso que não tratam de forma depreciativa o corpo da artista, mas são direcionados para a crítica das normativas sociais.

Ao explorar um pouco mais esse trecho de entrevista é possível apontar para um conceitochave deste artigo: a noção de paródia. Michelle brinca e faz graça de si, de suas características físicas, de suas mazelas frente aos regimes de verdade que engendram seu modo de ser, configurando uma crítica a esses modelos. Assim, a figura da palhaça é constituída a partir do jogo de reconhecimento, exploração e exibição dos regimes de verdade que perpassam a artista. Nesse jogo, a composição da palhaça se configura como uma paródia da artista ao expor, ampliar, dilatar, distorcer e transformar as características pessoais para então se transpor para uma denúncia social.

Os primeiros significados que envolvem o termo paródia se referem a uma imitação cômica, envolvendo o ridículo e o grotesco. Giorgio Agamben (2007) apresenta a vinculação da paródia com o cômico a partir da origem da palavra. Segundo o autor, a palavra deriva de paroidous, que eram cânticos engraçados apresentados nos intervalos das rapsódias e que tinham o intuito de animar a plateia pela inversão dos acontecimentos anteriores de forma ridícula: "Por isso, chamaram tais cantos de paroidous, pois ao lado e para além do assunto sério inseriam outras coisas ridículas. A paródia é, portanto, uma rapsódia invertida, que transpõe o sentido para o ridículo, trocando as palavras." (AGAMBEN, 2007, p. 33).

Entretanto, segundo Linda Hutcheon (1985), as definições que correlacionam paródia e comicidade não abarcam todas as possibilidades de entendimento do conceito. De acordo com a 
autora, a paródia passa a ter reconhecimento na sua condição de autorreflexividade, gerada a partir dos processos de criação e recriação que lhes são pertinentes. Ambiguidade, transcontextualização, repetição diferenciada, inversão, metaficção, recodificação, são algumas propriedades que compõem os estudos sobre paródia. A paródia retoma, repete, reinventa e recontextualiza o que está sendo parodiado. Muito mais que uma imitação cômica, a paródia é uma prática que possibilita o distanciamento crítico no jogo entre semelhanças e diferenças, na pluralidade de signos que se tensionam, no que se refere tanto à forma quanto ao conteúdo do que é parodiado. A paródia é, portanto, um jogo de duplicidades. Ao parodiar, o artista evoca algo precedente e o recria, apresentando-o de outra forma, dando-lhe novos contornos e provocando outros olhares à forma pré-existente. Para a autora: "A paródia é, noutra formulação, repetição com distância crítica, que marca a diferença em vez da semelhança." (HUTCHEON, 1985, p. 17). Esse distanciamento possibilita a crítica e confere à paródia a característica de autorreflexividade. Ainda segundo Hutcheon (1985), pensar na paródia a partir de um conjunto de outros conceitos, que não apenas as relações com o riso e o cômico, alarga suas possibilidades de representação. De acordo com a autora, o substantivo grego significa "contracanto", pois é composto pelos elementos odos que significa 'canto' e para que em grego pode ter dois significados: "contra ou oposição" e "ao longo de". Para ela, a noção de "contra e oposição" são aspectos que conduzem ao cômico e ao riso, a partir da confrontação entre os elementos do que é parodiado. Por outro lado, quando a raiz etimológica é pensada como "ao longo de" pode criar a ideia de "[...] acordo, de intimidade em vez de contraste." (HUTCHEON, 1985, p. 48). A autora, então, enfatiza que se trata de um recurso que é regido pela inversão, pela repetição como diferença que pode ou não conter humor e, consequentemente, nada impõe à paródia o caráter de ridículo. Ressalta-se que a autora não ignora o caráter risível que permeia a paródia, entretanto, defende que esta pode ser constituída de diferentes formas, não necessariamente pelo viés cômico.

As práticas da palhaçaria feminina, que se apoiam no universo da própria artista, transitam tanto pelo risível como pelo não risível, principalmente em seus processos pedagógicos que buscam um trabalho sensível de aproximação das artistas com a rede discursiva que permeia seus corpos. Essa perspectiva pode, ainda, ser depreendida de uma das falas da artista-palhaça Adelvane Néia, em entrevista para a terceira edição da revista Palhaçaria Feminina, ao comentar que, em sua prática como formadora, ela não busca, necessariamente, o riso. Ela diz:

Diante de tanto riso e banalização, tenho me perguntado se fazer rir é o mais importante hoje. Costumo fazer entender que meu objetivo primeiro não é o riso propriamente dito, mas perguntarse o que faz sentido, para si mesmo agora. (NÉlA, 2015, p. 85).

Néia revela a necessidade de cuidado com a produção do riso de forma banal, assim como enfatiza que suas práticas buscam criar uma experiência significativa para as artistaspalhaças, mesmo que isso não passe necessariamente pelo risível. Com essas considerações, podemos pensar que a palhaçaria feminina não se apoia somente no riso e no cômico, principalmente em seu caráter pedagógico, o que aproxima essas práticas, mais uma vez, às características da paródia.

Da mesma forma, as noções de 'contra' e 'ao longo de', que perpassam a paródia, podem ser exploradas tanto no âmbito da composição da figura da palhaça quanto do universo pessoal da artista uma vez que envolve ao mesmo tempo uma contraposição crítica e uma proximidade com a rede discursiva que a artista experimenta. Com base no relato de Michelle sobre a construção da sua palhaça como lemanjá, é possível pensar na noção de contra, como uma contraposição aos discursos sobre um ideal de corpo feminino. A figura da lemanjá criada por Michele revela tanto os discursos sobre o corpo feminino que a inibiam quanto sua crítica por meio da decisão de exibir suas formas, possibilitando uma reflexão a respeito dos padrões de beleza. Paralelamente, podemos ver que a paródia que a artista faz de si pela palhaça também possibilita um caminhar junto, 'ao longo de' sua própria trajetória. Pela paródia a artista expõe o próprio corpo e os regimes de verdade que a atravessam, expõe a sua história e o que a constitui como sujeito.

Portanto, a paródia de si na palhaçaria feminina pode ser vista tanto na sua condição de 'contra e oposição' como de 'ao longo de', visto que coloca na mesma figura a contraposição crítica e a proximidade com os regimes de verdade que tangem a artista. A palhaça apresenta em sua forma e seu repertório os discursos inscritos no corpo da artista, ao mesmo tempo que exterioriza a crítica e a reinvenção de si. Dessa forma, é possível pensar a paródia como uma matriz da máscara-palhaça. Com efeito, as características dicotômicas da paródia também podem ser vistas como desencadeadoras do deslocamento entre um riso depreciativo e uma comicidade crítica, pois instigam uma reflexão sobre os discursos que forjam os corpos.

Se explorarmos esse recorte, sobre a construção do número da lemanjá pela artista Michelle, agora sob a perspectiva do conceito de paródia, proposto por Butler, é possível pensar no caráter de ruptura que a cena engendra. Ruptura com padrões corporais e de beleza e do próprio feminino. A ideia de paródia, na obra de Butler, se insere nesse contexto de ruptura com os quadros normativos. Diante da rede discursiva que interpela os sujeitos e os convoca a repetir padrões de comportamento, 
Butler (2002b) questiona se há outras maneiras de ocupar a lei, de desarticular as formas já estabelecidas de reconhecimento do sujeito em relação a gênero. Segundo a autora, por ser o gênero um ato corporal, uma construção dramática, que se dá diante do outro, algumas performances podem desestabilizar as categorias de gênero já instituídas e revelar o caráter "fantasístico" de suas criações (BUTLER, 2016, p. 251). Para Butler, a paródia pode se constituir como ato performativo subversivo e desestabilizador das categorias de gênero. Nas palavras da autora:

Como estratégia para descaracterizar e dar novo significado às categorias corporais descrevo e proponho uma série de práticas parodísticas baseadas numa teoria performativa de atos de gênero que rompem as categorias de sexo, gênero e sexualidade, ocasionando uma ressignificação subversiva e sua proliferação além da estrutura binária. (BUTLER, 2016, p. 13).

A autora enfatiza que gênero não é uma identidade estável, mas sim uma "repetição estilizada de atos" e que o corpo é "uma fronteira variável", uma "superfície permeável". A paródia traz à tona a possibilidade de performar o gênero nas mais diversas formas e por diferentes corpos, independentemente de sua condição anatômica e dos quadros heteronormativos. A paródia configura-se, portanto, como forma de desarticular as normas de gênero a partir de outras configurações corporais, de outras repetições parodísticas. Como explica a autora, "[...] assim como as superfícies corporais são impostas como o natural, elas podem tornar-se o lugar de uma performance dissonante e desnaturalizada, que revela o status performativo do próprio natural" (BUTLER, 2016, p. 252, grifos da autora).

Sara Salih (2017), por sua vez, apresenta o conceito de paródia na obra de Butler como toda e qualquer construção de gênero, tendo em vista sua "natureza imitativa", ou seja, de reprodução de modelos produzidos como verdades. A ideia de paródia então aparece como repetição discreta ou exagerada dos atos performativos que constituem as características de gênero, tanto como forma de ratificar identidades heterossexuais quanto de promover rupturas com os padrões heteronormativos. Conforme a autora, "[...] seria legítimo dizer que o gênero em geral é uma forma de paródia, mas que algumas performances de gênero são mais paródicas do que outras." (SALIH, 2017, p. 93).

Essa concepção de paródia revela o caráter de performatividade de gênero que pode se apresentar de maneira comum, até mesmo corriqueira, inserido nas condições de naturalização de gênero e outros mais dissonantes em relação aos modelos socialmente instituídos. Contudo, a noção de paródia na obra de Butler, como todo e qualquer ato performativo de gênero, não nos parece tão evidente e direta como sugere Salih. Embora essa perspectiva esteja presente, principalmente no que se refere ao seu caráter imitativo, na maioria das vezes, a noção de paródia é tratada na sua condição de ruptura e de prática dissonante com os modelos heteronormativos. A perspectiva de Salih a respeito do conceito de paródia na obra de Butler pode nos levar a pensar que todo e qualquer ato é uma paródia, seja em relação a gênero, seja em relação a qualquer outro marcador social, tendo em vista que são sempre repetições, reencenações de atos performativos anteriores, imitações de modelos construídos socialmente que não possuem um original.

É fundamental explorar a concepção de paródia em suas diferentes possibilidades para então definir os contornos desse conceito para este trabalho. Para tanto, propomos retomar um dos atributos básicos da paródia: a repetição. Em que a repetição parodística se diferenciaria da repetição própria de qualquer ato performativo?

A ideia de repetição nos estudos da performance ultrapassa a condição de substantivo da palavra e a inscreve como verbo, como ato que se duplica. Richard Schechner (2013) apresenta o conceito de repetição como a base de toda performance, com a noção de conduta restaurada. Essa ideia compreende os diferentes atos, rituais e rotinas que se repetem e constituem um repertório cultural de um grupo de pessoas. De acordo com o autor, trata-se de fragmentos, pedaços de comportamentos que são reproduzidos e recombinados em novos contextos. São atos repetidos separados do 'eu', muitas vezes executados sem consciência, pelos indivíduos. Conforme destaca o autor: "Para colocá-lo em termos pessoais, a conduta restaurada é um comportamento 'como se' eu fosse outra pessoa, 'como me disseram para fazer' ou 'como eu aprendi'." (SCHECHNER, 2013, p. 34, tradução nossa) ${ }^{7}$. O autor pontua ainda que nada é original e tudo é um conjunto de recombinações que se efetuam em novos contextos. As diferenças individuais se dão nas maneiras como cada sujeito reproduz, restaura, articula e recombina os comportamentos.

Nessa perspectiva, a noção de conduta restaurada vai ao encontro da ideia de Butler sobre gênero como ato performativo que se constitui e se perpetua nos processos de repetição dos diferentes atos sociais que interpelam os sujeitos. Do mesmo modo, também se aproxima da leitura de Salih a respeito do conceito de paródia na obra de Butler como uma reprodução de modelos precedentes. Dessa forma, uma conduta restaurada, como repetição, como recombinação de comportamentos pré-existentes, mantém a similaridade entre paródia e ato performativo. Então,

${ }^{7}$ No original em inglês: "To put it in personal terms, restored behavior is 'me behaving as if I were someone else', or 'as I am told to do', or 'as I have learn'." (SCHECHNER, 2013, p. 34). 
segue a pergunta: como a repetição da paródia se diferenciaria da repetição própria de qualquer ato performativo?

Propomos considerar a noção de paródia como repetição, enfatizando sua característica de distanciamento crítico, conforme apontado no início deste artigo. A noção de distanciamento crítico sugere conter uma ação consciente do sujeito sobre o ato reproduzido, gerando um tensionamento entre a semelhança em relação ao que é reconstituído e a diferença que o recontextualiza. A paródia como um ato performativo contém em suas estruturas a conduta restaurada, conquanto não em sua repetição inconsciente, aparentemente naturalizada, mas em sua intencionalidade de ruptura.

Talvez possamos pensar na paródia como numa dupla conduta restaurada, em que seu duplo, a repetição da repetição, apresenta-se como contingente de transformação radical em relação às matrizes parodiadas. A paródia, a partir de sua característica de distanciamento crítico, se insere nesse contexto de possibilidade de transgressão e ruptura, na ideia de performatividade de gênero, como uma atuação que tensiona os moldes estabelecidos socialmente. Por intermédio da característica de distanciamento crítico, a noção de paródia já não pode ser associada a todo e qualquer ato performativo de acordo com o viés da repetição e da reconfiguração de comportamentos sociais. Se pensarmos na paródia como dupla conduta restaurada, a noção de comicidade crítica também se evidencia, pois possibilita romper com padrões normativos que podem constituir um riso depreciativo sobre a condição humana. Assim, a conduta restaurada na sua característica de ratificação da norma e dos padrões pode gerar um riso depreciativo, uma vez que repete sem questionar, ao passo que a paródia na condição de dupla conduta restaurada pode alçar condições de deslocamento do riso autodepreciativo para um riso crítico.

Dito isso, é possível retomar o conceito de paródia e práticas parodísticas proposto por Butler. A noção de paródia aparece, repetidas vezes, associada a um ato performativo dissonante, hiperbólico e até mesmo exagerado, que acentua as relações entre o corpo e os marcadores sociais de gênero. A noção de hipérbole como um dos atributos da paródia geralmente está relacionada às práticas de travestimento, entretanto, também pode se referir aos comportamentos heteronormativos. A autora diz, nesse sentido, que "[...] o gênero é um 'ato', por assim dizer, que está aberto a cisões, sujeito a paródias de si mesmo, a autocríticas e 'aquelas exibições hiperbólicas do natural' que em seu exagero, revelam seu status fundamentalmente fantasístico." (BUTLER, 2016, p. 253).

É possível depreender ainda da obra de Butler (2002b) uma articulação a respeito da noção de hipérbole nas práticas parodísticas que remete ao que excede e confunde o que é dado como norma. Assim, a paródia na sua característica hiperbólica excede os referentes, ultrapassa os modelos, propiciando condições para a criação de novos códigos de reconhecimento dos sujeitos.

Na performance de Michelle, da palhaça como lemanjá, a ruptura se dá entre os códigos sociais que constituem a figura da mulher sereia e o corpo da artista, fora dos padrões de magreza ou sensualidade que definem a imagem. Michelle excede a norma, apresenta uma figura de padrões corporais magros em um corpo gordo dissonante, gerando um tensionamento, abrindo uma brecha para a criação de novos códigos. Até mesmo em seu primeiro relato sobre ter experimentado um figurino masculino, há um tensionamento, uma ruptura entre os marcadores de gênero e o corpo feminino a partir do caráter hiperbólico da máscara.

A paródia de si que estrutura a figura da palhaça por meio do distanciamento crítico, da hipérbole que possibilita exceder os códigos vigentes, também pode se constituir como uma prática que possibilita a criação de novos códigos de reconhecimento de gênero. A palhaçaria feminina se configura, portanto, como uma prática parodística de gênero, à medida que possibilita que as artistas compreendam e experimentem outras formas de performar a si mesmas. Igualmente, o trabalho com a máscara-palhaça também pode gerar o reconhecimento de outras performances de gênero por parte de quem assiste, da plateia.

Nesse sentido, cabe-nos tentar delinear a noção de práticas parodísticas e sua potência frente à composição da máscara e os modos de subjetivação das artistas. A noção de prática parodística se refere às diferentes práticas que possibilitam às sujeitas parodiar a si mesmas de forma crítica, expondo, concomitantemente, as relações de semelhança e diferença, entre os regimes de verdade que as atravessam e outras possibilidades de performatividades de si. Trata-se, de fato, de compreender as práticas parodísticas como práticas que subvertem e tensionam a conduta restaurada que as estruturam, por meio do caráter hiperbólico e acentuado entre a semelhança e a diferença crítica com o que está sendo parodiado.

Assim, é por intermédio da paródia que se dá o deslocamento entre os planos individuais e sociais na composição da máscara. O universo pessoal da artista se torna o ponto de partida para a elaboração de um trabalho que visa uma crítica social e que, portanto, não se refere à vida pessoal da artista, mas a transborda para atingir níveis sociais de reconhecimento. Quando o trabalho da artista se desloca do pessoal para a crítica social, as chances de uma comicidade autodepreciativa se diluem. A composição cômica não visa apontar a condição corporal da artista como um fracasso, mas, justamente o contrário, apontar como as normas e padrões sociais constituem diferentes corpos como algo inviável, ridículo ou fracassado. 
Para Butler, a normatividade de gênero interpela os sujeitos a habitar uma lei, a se expressar e atuar num conjunto de regras para que sejam passíveis de reconhecimento. Entretanto, segundo a autora é no interior das próprias leis de significação que os processos de ruptura emergem, na incapacidade de repetição dos modelos, na variedade de configurações que as repetições podem gerar, nos fracassos em relação aos padrões sociais instituídos.

Se as regras que governam a significação não só restringem, mas permitem a afirmação de campos alternativos de inteligibilidade cultural, novas possibilidades de gênero que contestem os códigos rígidos dos binarismos hierárquicos, então é somente no interior das práticas de significação repetitiva que se torna possível a subversão da identidade. (BUTLER, 2016, p. 250).

A partir das afirmações de Butler é possível pensar que as noções de desajuste, de inadequação, de ridículo que constituem a máscara-palhaça podem gerar um campo alternativo de inteligibilidade se nos permitirmos considerar que o que as artistas reconhecem como fracasso pessoal está diretamente vinculado aos quadros normativos que impõem modos de subjetivação.

O fracasso da palhaça não é, portanto, uma denúncia ao fracasso da artista, mas uma possibilidade de crítica aos modelos sociais que geram padrões inviáveis de reconhecimento aos diferentes corpos, experiências e contextos. Na cena de Michelle, não se trata de apontar o corpo da artista como um fracasso diante dos padrões corporais, mas sim de apontar a vulnerabilidade da própria norma, seus limites diante da profusão de possibilidades de existência. Ao se colocar como lemanjá, expondo seu corpo de maneira graciosa, risível, poética, ela também abre espaço para outras configurações do feminino.

Foucault (2013) traz a ideia do corpo como o cerne de todas as utopias. O corpo com suas características físicas, situado em determinado espaço e tempo, forja um conjunto de emoções, desejos e pensamentos que constitui o indivíduo. A compreensão de si possibilita subvertê-lo, jogá-lo para outras possibilidades. Segundo o filósofo francês,

lá onde os caminhos e os espaços se cruzam, o corpo está em parte alguma: ele está no coração do mundo, este pequeno fulcro utópico, a partir do qual eu sonho, falo, avanço, imagino, percebo as coisas em seu lugar e também as nego pelo poder indefinido das utopias que imagino. (FOUCAULT, 2013, p. 14).

Ao encontro dessas ideias de Foucault, é possível pensar na figura da palhaça como o espaço do corpo utópico que, ao reconhecer sua forma e o que a atravessa, pode se reinventar. Por intermédio da paródia de si a artista percebe seu lugar e se coloca como crítica, como denúncia a partir da máscara. Igualmente, ela avança e se potencializa pela capacidade de contrapor e recriar o que a constitui.

O caráter pedagógico das práticas parodísticas se configura, justamente, nas possibilidades de reconhecimento, ruptura e reinvenção que constituem a paródia, nos processos de constante autocrítica que geram deslocamentos entre o que é pessoal e o que é socialmente constituído e que podem instigar novas operações sobre si mesmas. Ao explorar as possibilidades de performar a palhaça, as artistas podem encontrar espaço para criar outras formas de performar a si.

\section{Rir de si mesma como denúncia à norma}

Até o momento, as reflexões apresentadas constroem a noção de prática pedagógica parodística como os diferentes atos performativos que possibilitam as artistas parodiarem o próprio modo de ser, por meio de uma ação crítica subversiva sobre si e sobre os regimes de verdade que as forjam. Práticas pedagógicas parodísticas que a partir de repetições subversivas, visam a transformação dos modos de subjetivação e possibilitam a criação de novos códigos de reconhecimento capazes de constituir a figura da palhaça e de reverberar nos modos de subjetivação da artista numa relação constante. Contudo, é preciso pensar que se, por um lado, as práticas pedagógicas parodísticas podem gerar um posicionamento crítico por intermédio do rir de si mesma, do parodiar a si mesma, por outro lado, podem criar espaço para práticas autodepreciativas. Qual seria o limite entre uma comicidade crítica e um humor autodepreciativo?

Quando as práticas pedagógicas da palhaçaria feminina se apoiam no universo pessoal da artista por intermédio da paródia de si, a figura da palhaça expõe a rede discursiva que atravessa seus corpos, suas ações e suas emoções. Emerge de nossa análise e, sobretudo, da vivência com as artistas, a ideia de que, a figura da palhaça se configura por meio do que a artista percebe como inadequado em seu corpo e em seu comportamento. O fracasso da palhaça é, portanto, construído a partir da impossibilidade da artista de perpetuar os atos performativos a que foi interpelada ao longo de sua existência. Assim, ela coloca em evidência modelos sociais e de comportamento que afetam os modos de subjetivação, que captam os sujeitos, sem que eles mesmos percebam. A figura da palhaça vai se delineando por intermédio da busca desse universo pessoal, dado como inadequado, ridículo, torpe, grotesco e que se constitui no descompasso com as categorias de comportamento regidas pelas normas de adequação. 
Dessa forma, trata-se de uma crítica, não ao modo de ser da artista, mas sim aos padrões e às normas que estabelecem uma maneira hegemônica de existência, embora as duas dimensões sejam copartícipes das diferentes performances (artísticas e sociais). $O$ fracasso que a palhaça performa é a exposição de uma rede discursiva que não legitima diferentes formas de ser. A paródia de si que a palhaçaria feminina carrega em suas práticas denuncia o fracasso, novamente, não da artista, mas dos modelos hegemônicos de gênero e de outras matrizes sociais. Butler pontua que a ideia de fracasso individual está intimamente ligada ao fracasso das normas sociais. Nas palavras da autora: "Em nossa vulnerabilidade individual a uma precariedade que é socialmente induzida, cada 'eu' vê potencialmente como seu sentido particular de ansiedade e fracasso tem estado implicado todo tempo em um mundo social mais amplo." (BUTLER, 2018, p. 28).

Torna-se, portanto, evidente em nossa pesquisa a tentativa de desenvolver os processos pedagógicos da palhaçaria feminina com um olhar para a rede social que constitui as sujeitas e que se revela nas práticas de composição da figura da palhaça. Um olhar que desloca a noção de fracasso do pessoal para o social. Segundo Burnier (2009, p. 206), "[...] o palhaço circense e o clown possuem uma mesma essência: colocar em exposição a estupidez do ser humano, relativizando normas e verdades sociais." Dessa perspectiva, ainda, é possível depreender que, justamente, quando a exploração do universo pessoal se transpõe para a compreensão do que socialmente os corpos-artistas, os corpos-palhaças instauram, a máscara atinge seu caráter social. É, então, por intermédio de uma prática pedagógica parodística que as palhaças evocam a máscara, possibilitando um posicionamento crítico de si, ao mesmo tempo que uma crítica social. Dessa forma, abrem a possibilidade de se afastar de uma comicidade autodepreciativa, de um riso preconceituoso e destrutivo, aproximando-se de uma comicidade de si, de uma paródia de si libertadora.

\section{Referências}

AGAMBEN, Giorgio. Profanações. São Paulo: Boitempo, 2007.

BOLOGNESI, Mário Fernando. "Circo e teatro: aproximações e conflitos". Sala Preta, São Paulo, v. 6, p. 9-19, 2006.

BOLOGNESI, Mário Fernando. Palhaços. São Paulo: Ed. da Unesp, 2003.

BURNIER, Luís Otávio. A arte de ator: da técnica à representação. 2. ed. Campinas: Ed. da Unicamp, 2009.

BUTLER, Judith. [Entrevista cedida a] Baukje Prins e Irene Costera Meijer. "Como os corpos se tornam matéria: entrevista com Judith Butler". Revista Estudos Feministas, Florianópolis, v. 10, n. 1, p. 155167, 2002a. Disponível em https://periodicos.ufsc.br/index.php/ref/article/view/S0104026X2002000100009/8771. ISSN 1806-9584. http://dx.doi.org/10.1590/S0104-026X2002000100009. Acesso em 16/09/2020.

BUTLER, Judith. Corpos em aliança e a política das ruas: notas para uma teoria performativa de assembleia. Rio de Janeiro: Civilização Brasileira, 2018.

BUTLER, Judith. Cuerpos que importan: sobre los límites materiales y discursivos del "sexo". Buenos Aires: Paidós, 2002b.

BUTLER, Judith. Problemas de gênero: feminismo e subversão da identidade. 12. ed. Rio de Janeiro: Civilização Brasileira, 2016.

BUTLER, Judith. Relatar a si mesmo: crítica da violência ética. Belo Horizonte: Autêntica, 2015.

CAMOZZATO, Viviane Castro. "Pedagogias do presente". Educação \& Realidade, Porto Alegre, v. 39, n. 2, p. 573-593, abr./jun. 2014.

CASTRO, Alice Viveiros de. O elogio da bobagem: palhaços no Brasil e no mundo. Rio de Janeiro: Família Bastos, 2005.

FOUCAULT, Michel. O corpo utópico, as heterotopias. São Paulo: N-1 Edições, 2013.

HUGILL, Beryl. Bring on the clowns. Secaucus: Chartwell Books, 1980.

HUTCHEON, Linda. Uma teoria da paródia: ensinamentos das formas de arte do século XX. Rio de Janeiro: Ediçõos 70, 1985.

JUNQUEIRA, Mariana Rabelo. Da graça ao riso: contribuições de uma palhaça sobre a palhaçaria 
feminina. 2012. Mestrado (Programa de Pós-Graduação em Artes Cênicas) - Centro de Letras e Artes da Universidade Federal do Estado do Rio de Janeiro, Rio de Janeiro, RJ, Brasil.

LECOQ, Jacques. O corpo poético: uma pedagogia da criação teatral. São Paulo: SENAC São Paulo: SESC São Paulo, 2010.

LEITE, Amanda Dias. Aspectos do processo de abertura à participação feminina na palhaçaria brasileira: especificidades da produção carioca nas décadas 1980 e 1990. 2015. Mestrado (Programa de Pós-Graduação em Artes) - Escola de Belas Artes da Universidade Federal de Minas Gerais, Belo Horizonte, MG, Brasil. Disponível em https://repositorio.ufmg.br/handle/1843/EBACABFMX2. Acesso em 16/09/2020.

LOURO, Guacira Lopes. "Gênero e sexualidade: pedagogias contemporâneas". Pro-Posições [online]. Campinas, v. 19, n. 2, p. 17-23, maio/ago. 2008. Disponível em http://www.scielo.br/pdf/ pp/v19n2/a03v19n2.pdf. e-ISSN 1980-6248. http://dx.doi.org/10.1590/\$0103-73072008000200003. Acesso em 16/09/2020.

MIRANDA, Maria Brígida de. "Rainhas, sutiãs queimados e bruxas contemporâneas: reflexões a partir da montagem Vinegar Tom". Urdimento: Revista de Estudos em Artes Cênicas [online]. Florianópolis, v. 2, n. 11, p. 133-146, dez. 2008. Disponível em http://www.revistas.udesc.br/index.php/urdimento/ article/view/1414573102112008133/8882. e-ISSN 2358-6958. http://dx.doi.org/10.5965/ 1414573102112008133 . Acesso em 16/09/2020.

NÉIA, Adelvane. "A palavra da monsieur: qual é sua graça palhaça?". Palhaçaria Feminina, Chapecó, n. 3, p. 85-87, 2015.

REIS, Demian Moreira. Caçadores de risos: o maravilhoso mundo da palhaçaria. Salvador: EDUFBA, 2013.

SALIH, Sara. Judith Butler e a teoria queer. Belo Horizonte: Autêntica, 2017.

SANTOS, Sarah Monteath dos. Mulheres palhaças: percursos históricos da palhaçaria feminina no Brasil. 2014. Mestrado (Programa de Pós-Graduação em Artes) - Instituto de Artes da Universidade Estadual Paulista, São Paulo, SP, Brasil. Disponível em http://repositorio.unesp.br/bitstream/handle/ 11449/108810/000772305.pdf. Acesso em 16/09/2020.

SCHECHNER, Richard. Performance studies: an introduction. 3. ed. London: Routledge, 2013.

SILVA, Erminia. As múltiplas linguagens da teatralidade circense. In: CONGRESSO DA ASSOCIAÇÃO BRASILEIRA DE PESQUISA E PÓS-GRADUAÇÃO EM ARTES CÊNICAS, 3, 2003, Florianópolis, ABRACE. Anais... Florianópolis: ABRACE, 2003. p. 38-40.

SILVA, Erminia; ABREU, Luís Alberto de. Respeitável público...: o circo em cena. Rio de Janeiro: FUNARTE, 2009.

Ana Carolina Muller Fuchs (ana.fuchs@ufrgs.br) é artista-palhaça, professora de teatro e pesquisadora. Graduada em Educação Artística com habilitação em Artes Cênicas, mestre e doutoranda em Educação pela Universidade Federal do Rio Grande do Sul. Atualmente é professora de teatro do Colégio de Aplicação dessa universidade.

Gilberto Icle (gilbertoicle@pq.cnpq.br) é ator, diretor e pesquisador. Graduado em Teatro, mestre e doutor em Educação pela Universidade Federal do Rio Grande do Sul. Professor permanente do Programa de Pós-Graduação em Educação dessa universidade e do Programa de PósGraduação em Artes Cênicas da Universidade de Brasília. Editor-chefe da Revista Brasileira de Estudos da Presença. Bolsista de Produtividade 1D do CNPq. 


\section{COMO CITAR ESSE ARTIGO DE ACORDO COM AS NORMAS DA REVISTA}

FUCHS, Ana Carolina Muller; ICLE, Gilberto. "Comicidade crítica e riso autodepreciativo: um estudo com mulheres palhaças". Revista Estudos Feministas, Florianópolis, v. 28, n. 3, e61738, 2020.

\section{CONTRIBUIÇÃO DE AUTORIA}

Ana Carolina Muller Fuchs: Concepção, coleta de dados e análise de dados, elaboração do manuscrito, redação, discussão de resultados.

Gilberto Icle: Concepção, análise de dados, elaboração do manuscrito, redação, discussão de resultados.

\section{FINANCIAMENTO}

CNPq.

\section{CONSENTIMENTO DE USO DE IMAGEM}

Não se aplica.

APROVAÇÃO DE COMITÊ DE ÉTICA EM PESQUISA

Não se aplica.

\section{CONFLITO DE INTERESSES}

Não se aplica.

LICENÇA DE USO

Este artigo está licenciado sob a Licença Creative Commons CC-BY International. Com essa licença você pode compartilhar, adaptar, criar para qualquer fim, desde que atribua a autoria da obra.

\section{HISTÓRICO}

Recebido em 25/02/2019

Reapresentado em 05/08/2019

Aprovado em 22/10/2019

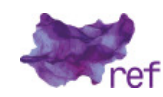

